\title{
SEKOLAH MENENGAH TINGKAT PERTAMA TERBUKA (SMP TERBUKA) SEBAGAI BENTUK PENDIDIKAN YANG MERAKYAT
}

Oleh: Sudirman Siahaan *)

\section{Abstrak}

Dalam kondisi perekonomian yang sulit, yang menjadi prioritas adalah bagaimana dapat bertahan hidup. Atau, yang menjadi prioritas dalam kehidupan sehari-hari adalah makan atau urusan "perut". Setiap orang berupaya dengan berbagai cara mendapatkan makanan. Yang dipentingkan adalah "perut kenyang". Berbagai kebutuhan hidup sehari-hari lainnya cenderung disisihkan untuk sementara dan baru menjadi perhatian apabila perut sudah kenyang. Dalam kondisi yang demikian ini, aspek kesehatan dan pendidikan menjadi "kurang mendapat perhatian". Penghasilan difokuskan untuk membuat "perut" kenyang. Berbagai bentuk pengeluaran lainnya terpaksa ditunda atau ditekan menjadi seminimal mungkin. Di antara berbagai biaya pengeluaran lainnya yang dinilai sangat mendasar adalah memenuhi kebutuhan akan kesehatan dan pendidikan. Bagaimana menyekolahkan anak-anak apabila kondisi keuangan (a) tidak atau kurang mendukung, atau (b) hanya cukup untuk memenuhi kebutuhan makan sehari-hari? Sejalan dengan Wajib Belajar 9 Tahun, para orang tua seyogianya mengupayakan anak-anak mereka dapat menyelesaikan pendidikan 9 Tahun. Sekalipun kondisi masyarakat kurang menguntungkan secara finansial, namun anak-anak usia SMP sebenarnya masih dapat menyelesaikan pendidikan SMP, yaitu melalui Sekolah Menengah Pertama Terbuka (SMP Terbuka) yang tersebar di setiap propinsi. SMP Terbuka dikatakan sebagai bentuk pendidikan yang merakyat karena antara lain: (a) pendidikan yang mendatangi anak-anak, (b) anak-anak tetap dapat membantu orang tua mencari nafkah sehari-hari, (c) anak-anak tidak harus datang setiap hari belajar di SMP, (d) anak-anak tidak perlu memakai seragam, (e) orang tua tidak dibebani berbagai bentuk biaya pendidikan, dan (f) kegiatan pembelajaran mengoptimalkan pemanfaatan berbagai sumber belajar di lingkungan sekitar.

Kata-kata Kunci: SMP Terbuka, belajar mandiri, tutorial tatap muka, pendidikan yang merakyat

\section{A. PENDAHULUAN}

\section{Latar Belakang Permasalahan}

Masyarakat masih belum sepenuhnya pulih dari akibat krisis moneter (krismon) yang terjadi, krisis global datang menerpa. Dampak krisis global yang sangat dirasakan masyarakat adalah tutup atau bangkrutnya berbagai perusahaan yang pada akhirnya bermuara pada pemutusan hubungan kerja (PHK) pekerja. Kehilangan pekerjaan yang mengakibatkan pengangguran di satu sisi, dan semakin sulitnya mencari pekerjaan di sisi yang lain, sangat berpengaruh terhadap

*) Sudirman Siahaan adalah tenaga fungsional peneliti di bidang pendidikan pada Pusat Teknologi Informasi dan Komunikasi (Pustekkom)-Departemen Pendidikan Nasional. 
kehidupan perekonomian keluarga sehari-hari.

Menghadapi kesulitan hidup yang dirasakan semakin berat, sebagian masyarakat harus berjuang keras untuk tetap dapat bertahan hidup. Dengan kata lain, masalah "perut" menjadi kebutuhan hidup sehari-hari yang sangat tinggi prioritasnya untuk dipenuhi. Sebagai konsekuensinya, kebutuhan lainnya yang dinilai sangat mendasar yang membutuhkan dukungan dana/biaya, seperti kebutuhan akan pendidikan dan kesehatan untuk sementara waktu "terpaksa" ditangguhkan atau "kurang mendapat perhatian".

Sehubungan dengan kondisi sulitnya kehidupan sehari-hari, maka yang menjadi masalah adalah "Bagaimana menyekolahkan anak-anak (khususnya pada satuan pendidikan SMP) apabila kondisi keuangan (a) tidak atau kurang mendukung, atau (b) hanya cukup untuk memenuhi kebutuhan makan seharihari?".

Sejalan dengan Wajib Belajar 9 Tahun, para orang tua seyogianya tetap mengupayakan agar anak-anak mereka setidak-tidaknya dapat menyelesaikan pendidikan 9 Tahun. Sekalipun kondisi masyarakat kurang menguntungkan secara finansial, namun anak-anak usia sekolah haruslah tetap melanjutkan pendidikannya sehingga setidak-tidaknya dapat menyelesaikan pendidikan SMP. Dalam kaitan ini, salah satu alternatif pendidikan yang merakyat yang tersebar di setiap propinsi adalah Sekolah Menengah Pertama Terbuka (SMP Terbuka).

SMP Terbuka dikatakan sebagai bentuk pendidikan yang merakyat karena antara lain ditandai dengan karakteristiknya, seperti: (a) pendidikan yang mendatangi anak-anak, (b) anak-anak tetap dapat membantu orang tua mencari nafkah sehari-hari, (c) anak-anak tidak harus datang setiap hari belajar di SMP, (d) anak-anak tidak perlu memakai seragam, (e) orang tua tidak dibebani berbagai bentuk biaya pendidikan, dan (f) kegiatan pembelajaran mengoptimalkan pemanfaatan berbagai sumber belajar di lingkungan sekitar.

\section{Dorongan untuk Menulis SMP Terbuka sebagai Bentuk Pendidikan yang Merakyat}

Penulisan artikel ini didorong oleh pengalaman penulis mengunjungi Sekolah Menengah Pertama Terbuka (SMP Terbuka) di berbagai daerah. Dalam kunjungan dan pengamatan langsung tentang penyelenggaraan SMP Terbuka, berbagai perasaan takjub/ bangga berbaur sekaligus dengan perasaan prihatin. Perasaan takjub/ bangga karena melihat semangat dan motivasi belajar yang tinggi yang diperlihatkan oleh anak-anak lulusan Sekolah Dasar (SD)/Madrasah Ibtidaiyah (MI). Demikian juga halnya dengan para fasilitator/tutor (Guru Pamong) yang memperlihatkan ketulusan dan dedikasi mereka yang tinggi untuk mendampingi peserta didik belajar. Keprihatinan yang mencuat adalah menyaksikan para guru mata pelajaran (Guru Bina) yang dengan penuh semangat mendatangi peserta didik di tempatnya guna memberikan kegiatan belajar tutotial tatap muka sekalipun harus melalui hutan dan menginap di rumah penduduk.

Dorongan lain yang menggugah penulis untuk mengetengahkan topik "SMP Terbuka sebagai Bentuk Pendidikan yang Merakyat" adalah hasil pengamatan terhadap anak-anak Iulusan Sekolah Dasar (SD) yang belum sepenuhnya dapat menikmati layanan pendidikan Sekolah Menengah Pertama (SMP) yang tersedia. Mereka adalah anggota masyarakat yang berada "jauh dari berbagai kemudahan". Berbagai bentuk kemudahan yang dimaksudkan dalam hal ini antara lain adalah mengakses layanan pendidikan, layanan sarana transportasi, sarana komunikasi, sumber tenaga listrik, dan kemungkinan juga kemudahan mengakses berbagai sumber informasi. Salah satu contoh konkrit adalah ketika penulis melakukan kegiatan pengamatan 
terhadap penyelenggaraan pendidikan SMP Terbuka di salah satu kabupaten di Propinsi Riau. Dalam kaitan ini, untuk dapat menjangkau peserta didik dibutuhkan kesabaran dengan perjalanan yang cukup melelahkan.

Untuk menjangkau lokasi SMP Negeri yang berfungsi sebagai sekolah induk SMP Terbuka dari ibukota Kabupaten dapat digunakan mobil atau sepeda motor sampai ke pinggiran sungai. Kemudian perjalanan dilanjutkan dengan menggunakan "getek" atau "klotok" menyeberangi sungai. Setelah itu, dengan menggunakan sepeda atau sepeda motor, barulah sekolah induk dapat dicapai. Para guru mata pelajaran yang bertugas atau mengajar di sekolah induk inilah yang menjadi Guru Bina SMP Terbuka. Dari lokasi sekolah induk ini, perjalanan dilanjutkan dengan menggunakan sepeda motor untuk tiba di tepian sebuah sungai. Di tepian sungai ini telah siap sampan carteran untuk mengunjungi peserta didik SMP Terbuka atau masyarakat handai tolan yang terdapat di beberapa "dusun" atau "kampung". Sungai ini membelah hutan dan merupakan "satu-satunya jalan" untuk menjangkau beberapa TKB SMP Terbuka.

Sampan yang bersiap-siap di tepi sungai adalah sampan yang telah terlebih dahulu dipesan pada hari-hari sebelumnya. Sampan ini hanya berkapasitas antara 4 sampai dengan 5 orang dan dilengkapi dengan mesin atau motor tempel. Sampan inilah yang biasanya dicarter para Guru Bina untuk mengunjungi peserta didik SMP Terbuka yang terdapat di beberapa TKB. Yang unik dalam perjalanan menggunakan sampan ini adalah bahwa apabila permukaan sungai melebar dan kedalaman sungai menjadi sangat dangkal, maka terpaksalah "sampan naik orang". Artinya, para penumpang turun dari sampan dan kemudian bersama-sama memikul sampan sampai ke permukaan sungai yang menyempit dengan kedalaman yang memadai untuk dilalui sampan. Sepanjang perjalanan ke lokasi TKB, hanya hutan yang menjadi pemandangan, baik di sisi kiri maupun kanan sungai disertai dengan suara binatang atau "penghuni hutan".

Pada umumnya, Guru Bina bertugas menyelenggarakan kegiatan belajar tutorial tatap muka kepada peserta didik SMP Terbuka satu atau dua kali setiap minggunya. Kegiatan belajar tutorial tatap muka dapat dilaksanakan di sekolah induk, di TKB, atau di tempat lain yang memungkinkan semua peserta didik dapat berkumpul untuk belajar. Namun untuk sampel SMP Terbuka seperti yang telah disebutkan, Guru Bina yang mendatangi peserta didik. Mengingat kondisi geografis yang ada, Guru Bina harus menginap di rumah penduduk setiap kali menyelenggarakan kegiatan belajar tutorial tatap muka.

Akibat yang lebih jauh lagi adalah bahwa Guru Bina tidak dapat menyelenggarakan kegiatan belajar tutorial tatap muka setiap minggu karena biaya operasional yang tinggi sehingga frekuensi pelaksanaannya tidak lagi sekali setiap minggu, melainkan hanya 1 - 2 kali setiap semester. Menghadapi masalah yang demikian ini dan mengupayakan agar kegiatan pembelajaran dengan Guru Bina dapat dilaksanakan secara teratur setiap minggunya, maka di beberapa lokasi SMP Terbuka yang sejenis telah diterapkan pemanfaatan teknologi radio komunikasi 2 arah.

\section{Tujuan Penulisan}

Yang menjadi tujuan dari penulisan artikel tentang "SMP Terbuka sebagai Bentuk Pendidikan yang Merakyat" adalah untuk berbagi informasi mengenai penyelenggaraan pendidikan yang bersifat merakyat (diselenggarakan sesuai dengan tuntutan perkembangan kebutuhan masyarakat akan layanan pendidikan) yang memungkinkan anakanak lulusan SD/MI di berbagai wilayah, baik yang terkendala secara geografis, ekonomis, maupun terkendala secara waktu dapat mengikuti pendidikan di SMP reguler yang ada. 


\section{B. KAJIAN LITERATUR}

\section{Konsep Pendidikan SMP Terbuka}

a. SMP Terbuka sebagai Subsistem Sekolah Menengah Tingkat Pertama merupakan salah satu subsistem pendidikan jalur sekolah yang memberikan pelayanan pendidikan tingkat SMP melalui prinsip belajar mandiri. Status SMP Terbuka sama dengan SMP biasa/reguler, baik ditinjau dari kurikulum, mutu maupun statusnya (Haryono, 1984). SMP Terbuka yang ada selama ini adalah juga SMP Negeri namun dengan kegiatan pembelajaran yang berbeda. Peserta didik SMP Terbuka mempunyai hak untuk memperoleh pendidikan dan ijazah yang sama dengan peserta didik SMP biasa/ reguler (Rahadi, 2005).

Berbagai ketentuan lain yang berlaku di SMP reguler diberlakukan juga pada SMP Terbuka, seperti misalnya: kurikulum yang digunakan, sistem penilaian hasil belajar, persyaratan calon peserta didik (harus lulus SD/ MI, usia antara 13-15 tahun), dan ijazah yang diberikan kepada para lulusan. Yang menjadi perbedaan antara SMP Terbuka dengan SMP reguler adalah terletak pada strategi kegiatan pembelajaran yang diterapkan (Siahaan, 2005).

Sasaran umum SMP Terbuka adalah (1) peserta didik yang tidak dapat ditampung di SMP biasa/regular, (2) peserta didik SMP reguler yang putus sekolah (drop-outs SMP), (3) anakanak Iulusan SD/MI di daerah terpencil dan terisolasi yang tidak ada SMP-nya, dan anak-anak dari keluarga tidak mampu yang terpaksa tidak bersekolah karena harus membantu orang tua mencari nafkah (Sadiman, 1999).

Sebagian besar kegiatan pembelajaran yang diterapkan di SMP Terbuka adalah belajar mandiri dengan megoptimalkan pemanfaaan berbagai sumber belajar di lingkungan sekitar peserta didik dengan seminimal mungkin bantuan orang lain. Bahan belajar utama yang digunakan di SMP Terbuka adalah bahan belajar mandiri tercetak (modul).

b. Strategi Pembelajaran di SMP Terbuka

Pada umumnya, peserta didik SMP Terbuka belajar secara mandiri, baik secara individual di tempat masingmasing sesuai dengan waktu yang dimiliki maupun secara bersamasama datang ke Tempat Kegiatan Belajar (TKB) pada sore hari setelah mereka selesai membantu orang tua masing-masing bekerja mencari nafkah kehidupan sehari-hari. Yang digunakan sebagai TKB dapat saja antara lain gedung Sekolah Dasar (SD) yang tidak digunakan pada sore hari, Balai Desa, atau bahkan juga rumah-rumah penduduk yang memungkinkan.

Di TKB inilah, para peserta didik berkumpul dan belajar dengan teman-temannya (sosialisasi). Peserta didik berpakaian bebas (tidak ada tuntutan untuk menggunakan pakaian seragam sebagaimana halnya dengan peserta didik SMP reguler) dan tidak ada keharusan untuk memakai sepatu. Untuk memfasilitasi kegiatan belajar peserta didik, diangkatlah seorang fasilitator/ tutor (Guru Pembimbing) yang berasal dari kalangan masyarakat setempat.

Tidak ada persyaratan khusus mengenai kualifikasi pendidikan bagi Guru Pembimbing. Yang dipentingkan adalah kesediaan anggota masyarakat yang sudah dewasa untuk meluangkan waktunya secara teratur (selama 4-5 hari setiap minggunya) membimbing, mengawasi, dan memotivasi peserta didik dalam kegiatan pembelajarannya. Para Guru Pembimbing pada umumnya adalah 
guru-guru SD, Kepala SD, pamong desa, atau orang tua yang terpanggil dan berkenan meluangkan waktunya. Secara faktual yang dijumpai di lokasi SMP Terbuka adalah bahwa para fasilitator/tutor pada umumnya adalah guru SD dan Kepala SD.

Peserta didik SMP Terbuka di setiap lokasi dikelompokkan ke dalam 3 sampai dengan 5 TKB. Setiap TKB dapat mengakomodasikan sekitar 1020 peserta didik. Pengelompokkan peserta didik ini pada umumnya dilakukan berdasarkan kedekatan tempat tinggal. Masing-masing TKB dapat mencakup 3 rombongan belajar yang terdiri atas peserta didik kelas VII, VIII, dan IX.

Sebagian besar waktu belajar peserta didik digunakan untuk belajar mandiri di TKB dan di tempat lainnya. Selain itu, peserta didik SMP Terbuka juga berkesempatan untuk belajar secara tatap muka (tutorial tatap muka) dengan guru mata pelajaran (Guru Bina) 1-2 kali setiap minggunya, baik yang diselenggarakan di sekolah induk maupun di tempat yang terdekat dengan tempat tinggal peserta didik. Tutorial tatap muka merupakan kegiatan pemberian layanan dan bantuan oleh Guru Bina kepada peserta didik SMP Terbuka dalam pemecahan berbagai kesulitan belajar yang ditemui/dialami peserta didik selama mereka melaksanakan kegiatan belajar mandiri di TKB, di rumah atau di tempat lain (Ibrahim, 2003).

Guru Bina dapat saja menyelenggarakan kegiatan belajar tutorial tatap muka di TKB atau di tempat lain yang dinilai lebih dekat dengan tempat tinggal peserta didik. Jika demikian ini keadaannya, berarti sumber belajar Guru Bina yang mendatangi peserta didik sehingga terjadi interaksi peserta didik dengan sumber belajar. Tetapi dapat saja terjadi bahwa peserta didik yang datang ke sekolah induk untuk mengikuti kegiatan belajar tutorial tatap muka yang diselenggarakan oleh Guru Bina.

Jika kegiatan belajar tutorial tatap muka diselenggarakan di sekolah induk, maka peserta didik tidak hanya dapat berinteraksi dengan Guru Bina sebagai salah satu sumber belajar tetapi peserta didik juga dapat berinteraksi dengan berbagai sumber belajar lainnya yang tersedia di sekolah induk, seperti: buku-buku teks yang tersedia di perpustakaan, media CD atau VCD pembelajaran yang tersedia, laboratorium yang dimiliki oleh sekolah induk, dan fasilitas olahraga.

Sebagaimana halnya dengan SMP reguler, evaluasi belajar peserta didik yang dilaksanakan di SMP Terbuka juga tidak berbeda. Evaluasi belajar di SMP Terbuka tidak hanya dilakukan oleh guru atau lembaga penyelenggara pendidikan tetapi juga oleh peserta didik sendiri. Ada 4 macam tes yang diselenggarakan, yaitu (a) tes mandiri (yang dilakukan sendiri oleh masing-masing peserta didik), (b) tes akhir modul, (c) tes akhir unit, dan (d) tes akhir semester. Kemudian, pada akhir semester keenam, peserta didik SMP Terbuka mengikuti ujian akhir (soal yang sama dengan yang diberikan kepada peserta didik SMP reguler) yang pelaksanaannya disesuaikan dengan SMP biasa/reguler (Rahadi, 2005).

c. Bahan Belajar

Bahan belajar utama yang digunakan di SMP Terbuka adalah bahan belajar mandiri tercetak yang disebut modul. Bahan belajar modul dirancang dan dikembangkan sedemikian rupa sehingga dapat dipelajari oleh masing-masing peserta didik secara mandiri di mana dan kapan saja. Bahan belajar modul didistribusikan Departemen Pendidikan Nasional sampai ke TKB sehingga peserta didik tidak perlu mencari sumber belajar modul tetapi sebaliknya, sumber belajar modul yang datang 
kepada peserta didik melalui TKB. Bahan belajar lainnya adalah yang berupa media elektronik, seperti: kaset audio/CD, kaset video/DVD/ VCD, dan siaran TV.

Bahan-bahan belajar untuk peserta didik SMP Terbuka dirancang dan dikembangkan secara khusus oleh sebuah tim pengembang yang terdiri dari para spesialis di berbagai bidang sehingga dimungkinkan untuk dipelajari peserta didik secara mandiri. Yang termasuk sebagai Tim Pengembang sumber belajar adalah (a) ahli materi yang berasal dari guru mata pelajaran di sekolah (pada umumnya adalah guru inti), (b) ahli materi dari perguruan tinggi (pengembang disiplin keilmuwan), (c) ahli pengembangan media yang berasal dari Pusat Teknologi Informasi dan Komunikasi Pendidikan (Pustekkom), dan (d) ahli pengembangan kurikulum dari Pusat Pengembangan Kurikulum (Puskur)Balitbang Diknas, dan (e) ahli penilaian pendidikan dari Pusat Pengembangan Penilaian Pendidikan (Puspendik)-Balitbang Diknas.

Bahan belajar lainnya yang juga dapat dimanfaatkan oleh peserta didik di tempatnya masing-masing adalah siaran televisi edukasi (TVE), kaset audio/CD, kaset video/DVD/VCD. Memang bahan-bahan belajar ini hanya dapat dimanfaatkan apabila tersedia fasilitas pemanfaatannya di lingkungan tempat tinggal peserta didik, seperti: pesawat TV dan DVD player. Kalau tidak tersedia di setiap keluarga, tentunya peserta didik dapat menumpang belajar di rumah tetangga yang memiliki pesawat TV atau peralatan DVD player. Apabila di komunitas setempat ada anggota masyarakat yang mempunyai antena parabola, maka siaran TVE dapat diikuti selama 24 jam dengan cara mengarahkan antena parabola ke satelit Telkom-1.

\section{Pemikiran SMP Terbuka sebagai Bentuk Pendidikan Kerakyatan}

Undang-undang Dasar 1945 mengamanatkan bahwa (a) pendidikan adalah tanggung jawab pemerintah, keluarga, dan masyarakat dan (b) setiap warga negara berhak mendapatkan pendidikan. Dalam kaitan ini, salah satu kebijakan pemerintah adalah Wajib Belajar 6 tahun pada tahun 1984 dan program Wajib Belajar 9 Tahun pada tahun 1994. Dalam rangka menuntaskan Wajib Belajar 9 Tahun, SMP Terbuka merupakan salah satu di antara berbagai pola layanan pendidikan yang diterapkan.

Pendidikan yang merakyat yang dimaksudkan di dalam tulisan ini adalah pendidikan yang pro rakyat kebanyakan, bukan hanya bagi kelompok masyarakat tertentu (masyarakat dengan kemampuan finansial yang memadai). Pendidikan yang merakyat memberikan kemudahan bagi masyarakat yang kurang beruntung (marginal), baik yang terkendala secara geografis, ekonomis, maupun waktu, untuk mendapatkan layanan pendidikan/pembelajaran.

Secara sederhana dapat dikatakan bahwa pendidikan yang merakyat ditandai antara lain dengan: (a) pendidikan yang mendatangi anak-anak, (b) anak-anak tetap dapat membantu orang tua mencari nafkah sehari-hari, (c) anak-anak tidak harus datang setiap hari belajar di SMP, (d) anak-anak tidak perlu memakai seragam, (e) orang tua tidak dibebani berbagai bentuk biaya pendidikan, dan (f) kegiatan pembelajaran mengoptimalkan pemanfaatan berbagai sumber belajar di lingkungan sekitar.

a. SMP Terbuka Menerapkan Kegiatan Belajar yang Fleksibel

SMP Terbuka dinilai sebagai model pendidikan yang efektif dan fleksibel menunjang Wajib Belajar 9 Tahun terutama untuk daerah-daerah yang terkendala secara geografis (pegunungan, dataran, dan pantai) dan yang menghadapi keterbatasan sarana mobilitas untuk menjangkau 
SMP reguler yang ada (Siahaan, 2002). Fleksibilitas SMP Terbuka terletak pada perkembangan kebutuhan masyarakat akan layanan pendidikan SMP.

Apabila masyarakat di suatu wilayah mempunyai kebutuhan akan layanan pendidikan SMP, tetapi tidak memungkinkan menyekolahkan anak-anak mereka ke SMP reguler yang ada, baik karena kondisi geografis yang sulit, jarak tempuh yang relatif jauh, maupun karena tidak tersedianya sarana transportasi untuk menjangkau lokasi SMP reguler, maka SMP Terbuka dapat diselenggarakan. Apabila kemudian pada suatu waktu, bahwa ternyata di lokasi yang sama tidak lagi dibutuhkan layanan pendidikan SMP, maka SMP Terbuka yang telah ada dapat ditutup. Oleh karena itu, pembukaan dan penutupan penyelenggaraan SMP Terbuka dapat dilakukan di mana dan kapan saja sesuai dengan tuntutan perkembangan kebutuhan masyarakat akan layanan pendidikan SMP (Siahaan, 2005).

Manakala masyarakat di suatu lokasi yang ada SMP Terbuka-nya sedang mengalami musin menanam, musim panen, atau musim penangkapan ikan, maka kegiatan pembelajaran di TKB dimungkinkan saja ditiadakan untuk sementara waktu. Manakala kesibukan masyarakat pada musim tertentu telah usai, maka kegiatan pembelajaran dapat dimulai kembali. Kondisi yang demikian inilah yang memperlihatkan bahwa kegiatan pembelajaran di SMP Terbuka bersifat fleksibel sesuai dengan kondisi yang berkembang di masyarakat.

Mengingat prinsip pembelajaran yang diterapkan di SMP Terbuka adalah belajar mandiri dengan menggunakan bahan-bahan belajar mandiri yang telah dipersiapkan secara khusus, maka setiap peserta didik dapat melaksanakan kegiatan belajarnya di mana dan kapan saja. Namun setiap sore hari, peserta didik memang dikondisikan untuk datang bersama-sama mengikuti kegiatan belajar mandiri di TKB. Di TKB inilah, peserta didik dapat melaporkan kemajuan kegiatan belajarnya dan sekaligus juga menyerahkan modul yang telah selesai dipelajari dengan nilai ketuntasan yang dipersyaratkan dan mengambil modul berikutnya yang akan dipelajari.

Apabila dinilai lebih sulit bagi para peserta didik untuk datang ke sekolah induk (SMP reguler yang ditunjuk), maka guru mata pelajaran dari sekolah induklah yang mendatangi peserta didik. Mengenai tempat pertemuan untuk penyelenggaraan kegiatan belajar tutorial tatap muka, dapat disepakati bersama antara Guru Bina dan peserta didik. Tempatnya dapat di TKB atau tempat lain yang tidak memberatkan peserta didik untuk datang belajar. Namun, yang menjadi masalah lagi adalah menjangkau para peserta didik yang berada di daerah terpencil, kondisi geografis yang sulit, dan keterbatasan sarana transportasi.

b. SMP Terbuka tidak Membebani Masyarakat

Pendidikan di SMP Terbuka tidak menuntut biaya dari para orang tua peserta didik. Sesuai dengan prinsip penyelenggaraannya yang mengoptimalkan pemanfaatan berbagai sumber belajar yang tersedia di lingkungan sekitar, maka anak-anak yang menjadi peserta didik SMP Terbuka tidak dipungut biaya. Tidak juga diharuskan menggunakan pakaian seragam, atau pembelian buku-buku atau bahan-bahan belajar yang akan digunakan peserta didik selama mengikuti pendidikan di SMP Terbuka. Bahkan para peserta didik SMP Terbuka juga mendapatkan bantuan beasiswa. Secara singkat 
dapat dikatakan bahwa para orang tua yang menyekolahkan anakanaknya ke SMP Terbuka tidak terbebani dengan berbagai bentuk biaya penyelenggaraan pendidikan.

Yang justru sangat dibutuhkan dari para orang tua adalah mendorong dan menggugah agar anak-anak mereka dapat menggunakan waktu mereka seoptimal mungkin secara teratur untuk belajar setelah selesai membantu orang tua bekerja mencari nafkah. Setiap peserta didik dimungkinkan untuk belajar secara teratur di mana dan kapan saja karena bahan belajar yang disediakan bagi mereka adalah bahan belajar mandiri. Demikian juga halnya dengan peran para fasilitator/tutor atau Guru Pembimbing dan Guru Bina. Mereka ini secara terus-menerus dituntut memotivasi peserta didik sehingga tergugah dan termotivasi untuk seoptimal mungkin memanfaatkan waktunya secara teratur belajar setiap hari.

c. SMP Terbuka Mengembangkan Keterampilan/Kecakapan Hidup (Life Skill)

Keterampilan/kecakapan hidup (Life Skill) merupakan kemampuan, keterampilan, dan kesanggupan yang diperlukan seseorang untuk menghadapi dan menjalankan kehidupan nyata sehari-hari (Subijanto, 2007). Setiap daerah mempunyai bentuk kecakapan hidup yang khas yang perkembangkannya dilakukan dengan cara mengajarkannya kepada generasi yang lebih muda. Melalui pembekalan peserta didik dengan kecakapan hidup, maka diharapkan peserta didik akan dapat mendatangkan penghasilan bagi dirinya sendiri.

Sesuai dengan prinsip SMP Terbuka yang mengoptimalkan pemanfaatan berbagai sumber belajar yang tersedia di lingkungan sekitar, maka anggota masyarakat yang memiliki berbagai keterampilan (misalnya: jahit-menjahit, bordir, pembudidayaan madu/lebah, sablon, kerajinan tangan, pembuatan makanan khas setempat) diminta kesediaannya oleh pengelola SMP untuk mengajarkan keterampilan yang dimiliki kepada para peserta didik SMP Terbuka. Permintaan pengelola SMP Terbuka kepada anggota masyarakat tertentu untuk membelajarkan para peserta didik di bidang keterampilan pada umumnya, dirasakan sebagai suatu kebanggaan atau kehormatan tersendiri.

Berbagai produk yang dihasilkan oleh peserta didik dijual kepada masyarakat, baik secara langsung maupun melalui unit-unit usaha yang ada tergantung jenis produk yang dihasilkan. Dana yang diperoleh digunakan untuk membeli bahanbahan yang diperlukan dalam memproses/menghasilkan produk yang berikutnya, baik yang sejenis maupun yang baru yang akan dipelajari. Dalam hal ini, para peserta didik dilatih untuk mengembangkan keterampilan yang menghasilkan dan sekaligus juga memasarkan produk. Namun pada akhir-akhir ini, semakin berkurang jumlah SMP Terbuka yang memberikan pembekalan peserta didiknya dengan keterampilan/ kecakapan hidup.

d. SMP Terbuka Memungkinkan Sumber Belajar Mendatangi Peserta Didik

Bilamana pada SMP reguler, para peserta didik yang mendatangi sumber belajar, baik yang berupa insani (guru) maupun non insani yang terdapat di sekolah. Sedangkan di SMP Terbuka, sumber belajar telah disediakan dan tersedia di lingkungan peserta didik. Para fasilitator/tutor atau Guru Pembimbing juga mendatangi peserta didik di TKB untuk mengarahkan mereka belajar mandiri dan berdiskusi. 
Sedangkan sumber belajar yang berupa Guru Bina, tergantung pada kondisi masing-masing lokasi SMP Terbuka. Adakalanya untuk daerah tertentu yang dinilai tidak memungkinkan peserta didik datang mengikuti kegiatan pembelajaran dari Guru Bina di sekolah induk, maka Guru Bina yang datang ke TKB atau tempat lain di mana peserta didik dapat dengan mudah berkumpul. Tetapi manakala kondisi yang ada memungkinkan peserta didik datang ke sekolah induk untuk mengikuti kegiatan pembelajaran dari Guru Bina, maka peserta didik dan Guru Bina yang datang ke sekolah induk

Sumber belajar lain yang dapat dimanfaatkan oleh peserta didik SMP Terbuka di tempatnya masing-masing (tentunya keluarga yang mempunyai fasilitas pesawat TV) adalah siaran televisi edukasi (TVE). Dengan pesawat TV biasa, siaran TVE dapat ditangkap melalui stasiun TVRI. Semenjak 17 Juli 2006, stasiun TVRI menerus-siarkan siaran TVE secara nasional setiap hari pada pukul 07.0009.00 WIB dan pukul 14.00-16.00 WIB. Jadwal siaran TVE tentunya dapat diperoleh/diketahui peserta didik dari sekolah induk (Pustekkom, 2007).

Selain TVRI, Pustekkom juga bekerjasama dengan berbagai stasiun TV lokal, operator TV Kabel, dan Pemerintah Daerah dalam menerus-siarkan program TVE (Leaflet Pustekkom). Mengingat kemajuan teknologi yang pesat, peralatan DVD player hampir dipastikan tidak sulit ditemukan di lingkungan masyarakat. Dalam kaitan ini, peserta didik juga dapat memanfaatkan VCD pembelajaran yang didistribusikan Departemen Pendidikan Nasional ke SMP Terbuka. Caranya adalah dengan meminjam VCD dari sekolah induk untuk dimanfaatkan secara bersama dalam kelompok. e. SMP Terbuka Diselenggarakan sesuai dengan Kondisi Masyarakat Sesuai dengan strategi pembelajaran yang diterapkan di SMP Terbuka, maka bahwa peserta didik sebagai anak di tengah-tengah keluarga tetap dapat melaksanakan kegiatan belajarnya dan sekaligus juga masih dapat membantu orang tua mencari nafkah kebutuhan hidup sehari-hari dari pagi sampai siang hari (urusan perut). Peserta didik SMP Terbuka barulah berkumpul untuk belajar mandiri di TKB pada sore hari.

Tujuan berkumpulnya peserta didik di TKB bukanlah untuk mengikuti kegiatan pembelajaran dari guru mata pelajaran sebagaimana yang terjadi di SMP reguler. Peserta didik berkumpul di TKB untuk melakukan kegiatan belajar mandiri di bawah bimbingan atau pengawasan tutor/ fasilitator atau yang biasanya disebut sebagai Guru Pembimbing . Kegiatan berkumpul ini juga sekaligus sebagai wahana sosialisasi bagi para peserta didik.

Di TKB inilah peserta didik belajar mandiri, baik secara individual, dalam kelompok-kelompok kecil maupun melakukan kegiatan diskusi. Peserta didik SMP Terbuka datang berkumpul ke TKB untuk belajar mandiri selama 4-5 hari setiap minggunya. Pada prinsipnya, selain di TKB, belajar mandiri dapat juga dilakukan oleh masing-masing peserta didik di mana saja dan kapan saja sesuai dengan ketersediaan waktu mereka.

Di samping bahan belajar mandiri tercetak (modul) sebagai bahan belajar utama, peserta didik SMP Terbuka pada awal perintisannya pada tahun 1979 dilengkapi juga dengan bahan belajar lainnya, seperti: media kaset audio, siaran radio, media kaset video, dan film bingkai suara (sound slide programs). Pada tahap perkembangan selanjutnya, bahan-bahan belajar yang diberikan kepada peserta didik 
adalah modul, CD dan VCD. Dengan adanya siaran televisi edukasi (TVE), peserta didik SMP Terbuka juga dapat memanfaatkan siaran TVE sebagai salah satu sumber belajar.

Sekali seminggu, peserta didik SMP Terbuka datang ke SMP Negeri yang terdekat yang ditunjuk sebagai sekolah induk SMP Terbuka. Di sekolah induk inilah peserta didik SMP Terbuka mengikuti kegiatan pembelajaran secara tatap muka atau yang disebut sebagai kegiatan belajar tutorial tatap muka. Tujuannya adalah untuk memberikan kesempatan kepada semua peserta didik mendiskusikan berbagai kesulitan yang mereka hadapi selama mereka melakukan kegiatan belajar mandiri, baik di TKB maupun di tempat lain.

f. SMP Terbuka Menjangkau Masyarakat Marginal

Sehubungan dengan keberadaan masyarakat di daerah terpencil, sulit geografis, keterbatasan sarana transportasi, dan waktu, maka pemanfaatan teknologi merupakan alternatif pemecahannya. Melalui pemanfaatan kemajuan teknologi, maka peserta didik yang berada di wilayah geografis yang sulit atau terpencil dan menghadapi keterbatasan sarana transportasi dimungkinkan untuk mendapatkan layanan pendidikan/pembelajaran. Dengan dukungan teknologi, pendidikanlah yang mendatangi peserta didik di tempatnya bukan sebaliknya, peserta didik yang mendatangi lembaga-lembaga pendidikan untuk mendapatkan layanan pendidikan/pembelajaran.

Teknologi yang dimaksudkan di sini adalah teknologi yang masih bersifat sederhana dan mudah pengoperasiannya. Teknologi yang dimaksudkan adalah radio komunikasi 2 arah (a two-way communication). Fasilitas radio komunikasi ini dipasang di SMP
Negeri yang berfungsi sebagai pusat sumber belajar yang akan membelajarkan para peserta pendidikan SMP Terbuka dan di masing-masing TKB. Sebelum pengoperasian, para Guru Bina, Guru Pembimbing, dan Pengelola SMP Terbuka diberikan kegiatan orientasi tentang pengenalan, pengoperasian, dan pemeliharaan/perawatan fasilitas radio komunikasi 2 arah, baik yang ada di sekolah induk maupun di masing-masing TKB.

Kemudian, dilakukan simulasi pemanfaatan fasilitas radio komunikasi dalam situasi pembelajaran yang nyata. Tujuannya adalah agar perangkat teknologi yang dipasang di sekolah induk dan di TKB dapat dimanfaatkan secara optimal sesuai dengan prosedur operasional standar (POS). Dengan memanfaatkan fasilitas radio komunikasi 2 arah ini, maka kegiatan pembelajaran tutorial tatap muka antara Guru Bina dengan peserta didik dapat diselenggarakan secara teratur setiap minggunya.

SMP Terbuka tidak hanya dapat dinikmati oleh anak-anak lulusan SD/ MI atau yang putus sekolah di SMP biasa/reguler yang berada di daerah terpencil dan terisolasi, sulit geografisnya, dan terbatas sarana transportasinya. SMP Terbuka juga dapat dinikmati oleh anak-anak yang berada di daerah perkotaan tetapi karena kondisi finansial tidak memungkinkan mengikuti pendidikan di SMP biasa/reguler.

\section{SIMPULAN DAN SARAN}

\section{Simpulan}

Pendidikan SMP Terbuka, sesuai dengan fleksibilitas yang dimilikinya, dapat diselenggarakan dan dihentikan di mana dan kapan saja sesuai dengan tuntutan perkembangan kebutuhan masyarakat akan layanan pendidikan SMP. Pada 
umumnya, peserta didik SMP Terbuka berasal dari kalangan masyarakat yang bertempat tinggal di daerah-daerah terpencil, sulit geografis dan sarana mobilitas, keterbatasan kemampuan finansial, atau terkendala secara waktu (terutama karena membantu orang tua mencari nafkah) untuk mengikuti pendidikan SMP yang reguler. Prinsip penyelenggaraan SMP Terbuka adalah bahwa peserta didik belajar secara mandiri dengan mengoptimalkan pemanfaatan berbagai sumber belajar yang tersedia di lingkungan masyarakat sekitar.

Dari hasil pengamatan di berbagai lokasi tentang pengelolaan SMP Terbuka, dapatlah disimpulkan bahwa SMP Terbuka merupakan bentuk pendidikan yang merakyat. Dikatakan demikian karena antara lain: pendidikanlah yang mendatangi anak-anak sehingga menjangkau masyarakat marginal (baik yang terkendala secara ekonomis, mobilitas, atau waktu), peserta didik tidak harus datang setiap hari belajar di SMP, peserta didik tetap dapat membantu orang tua mencari nafkah sehari-hari, mengembangkan keterampilan/ kecakapan hidup (life skill) peserta didik, tidak ada kewajiban peserta didik untuk memakai pakaian seragam, orang tua tidak dibebani berbagai bentuk biaya pendidikan, dapat diselenggarakan dan dihentikan sesuai dengan kebutuhan masyarakat akan layanan pendidikan SMP, dan mengoptimalkan pemanfaatan berbagai sumber belajar di lingkungan sekitar.

\section{Saran-saran}

Memperhatikan fleksibilitas penyelenggaraan pendidikan SMP Terbuka sebagai bentuk pendidikan yang merakyat dan kontribusinya dalam memberikan layanan pendidikan kepada masyarakat yang kurang beruntung (disadvantaged community) disebabkan karena kondisi geografis, ekonomis, sarana mobilitas, dan waktu, maka disarankan agar Pemerintah Kabupaten/ Kota: a. dapat lebih meningkatkan kuantitas dan kualitas penyelenggaraan pendidikan SMP Terbuka sehingga masyarakat yang sejauh ini belum atau kurang terlayani (under served atau unserved) di bidang pendidikan SMP akan semakin berkurang jumlahnya;

b. melakukan kajian mengenai pemanfaatan kemajuan teknologi untuk diterapkan dalam kegiatan pembelajaran pada jenjang pendidikan dasar dan menengah (khususnya pada satuan pendidikan SMP) sebagai salah satu upaya untuk menunjang percepatan penuntasan wajib belajar 9 tahun.

c. dapat lebih memberdayakan lembaga pendidikan SMP melalui (1) pelatihan guru-gurunya di bidang pemanfaatan teknologi dan (2) pengadaan berbagai fasilitas yang menunjang penyelenggaraan kegiatan pembelajaran sebagai salah satu upaya untuk peningkatan kualitas pendidikan.

\section{KEPUSTAKAAN}

Haryono, Anung. (1984). "Sekolah Menengah Terbuka: Suatu Penerapan Teknologi Pendidikan untuk Pemerataan Kesempatan Belajar" dalam Teknologi Komunikasi Pendidikan: Pengertian \& Penerapannya di Indonesia. Jakarta: Pusat Teknologi Komunikasi Pendidikan dan KebudayaanDepartemen Pendidikan dan Kebudayaan.

Ibrahim, Nurdin. (2003). "Hubungan Tempat

Tutorial Tatap Muka dengan Hasil Belajar Siswa SMP Terbuka" dalam Jurnal TEKNODIK No. 12/VIITEKNODIKI OKTOBER 2003. Jakarta: Pusat Teknologi Informasi dan Komunikasi PendidikanDepartemen Pendidikan Nasional.

Pustekkom. Leaflet Televisi Edukasi (TVE):

Santun dan Mencerdaskan. Jakarta: Pusat

Teknologi Informasi dan Komunikasi Pendidikan-Departemen Pendidikan Nasional.

Pustekkom. (2007). Pedoman Pemanfaatan Siaran Televisi Edukasi (TVE). Jakarta: Pusat Teknologi Informasi dan Komunikasi Pendidikan-Departemen Pendidikan Nasional. 
Rahadi, Aristo. (2005). "SMP Terbuka dan Dinamikanya: SMP Terbuka Sebagaimana Sebuah Sistem" dalam Purwanto (ed.) Jejak Langkah Perkembangan Teknologi Pendidikan di Indonesia. Jakarta: Pusat Teknologi Informasi dan Komunikasi Pendidikan-Departemen Pendidikan Nasional.

Sadiman, A. S. (ed.). (1999). Jaringan Sistem Belajar Jarak Jauh Indonesia (Jaringan Sistem BJJI). Jakarta: Pusat Teknologi Komunikasi Pendidikan dan Kebudayaan (Pustekkom).

Siahaan, Sudirman. (2002). "Studi tentang Pengelolaan Pendidikan Terbuka/Jarak Jauh di Era Otonomi Daerah di Kabupaten Deli Serdang-Propinsi Sumatera Utara" dalam Jurnal Pendidikan Terbuka dan Jarak Jauh
Vol. 3 No. 1 Maret 2002. Jakarta: Lembaga Penelitian-Universitas Terbuka.

Siahaan, Sudirman. (2005). Studi tentang Perintisan Pemanfaatan Media Terintegrasi (Media Kaset Audio dan Modul) untuk Pembelajaran Bahasa Inggris di SMP Terbuka. Jakarta: Pusat Teknologi Komunikasi dan Informasi Pendidikan-Departemen Pendidikan Nasional.

Subijanto. (2007). "Program Pendidikan Life Skills bagi Siswa Sekolah Menengah Atas di Wilayah Pesisir" dalam Jurnal Pendidikan dan Kebudayaan Tahun Ke-13, No. 066 Mei 2007. Jakarta: Badan Penelitian dan Pengembangan Departemen Pendidikan Nasional. 